\section{DIGITAL COMMONS \\ @ UNIVERSITY OF SOUTH FLORIDA}

\section{ABO: Interactive Journal for Women in the Arts, 1640-1830}

Volume 8

Issue 2 Volume 8, Issue 2 Fall 2018

Article 3

2018

\title{
Editing Aphra Behn in the Digital Age: An Interview with Gillian Wright and Alan Hogarth
}

\author{
Laura Runge \\ University of South Florida, runge@usf.edu \\ Gillian Wright \\ University of Birmingham, g.wright@bham.ac.uk \\ Alan Hogarth \\ University of Leicester, ajh108@leicester.ac.uk
}

Follow this and additional works at: https://digitalcommons.usf.edu/abo

Part of the Dramatic Literature, Criticism and Theory Commons, Educational Methods Commons, Feminist, Gender, and Sexuality Studies Commons, and the Literature in English, British Isles Commons

\section{Recommended Citation}

Runge, Laura; Wright, Gillian; and Hogarth, Alan (2018) "Editing Aphra Behn in the Digital Age: An Interview with Gillian Wright and Alan Hogarth," ABO: Interactive Journal for Women in the Arts, 1640-1830: Vol.8: Iss.2, Article 3.

https://doi.org/10.5038/2157-7129.8.2.1201

Available at: https://digitalcommons.usf.edu/abo/vol8/iss2/3

This Digital Humanities is brought to you for free and open access by Digital Commons @ University of South Florida. It has been accepted for inclusion in ABO: Interactive Journal for Women in the Arts, $1640-1830$ by an authorized administrator of Digital Commons @ University of South Florida. For more information, please contact digitalcommons@usf.edu. 


\title{
Editing Aphra Behn in the Digital Age: An Interview with Gillian Wright and Alan Hogarth
}

\author{
Abstract \\ This interview provides a view of the work in progress for the Cambridge University Press edition of the \\ Complete Works of Aphra Behn. Gillian Wright serves as a general editor (with Elaine Hobby, Claire \\ Bowditch, and Mel Evans) as well as the volume editor for Behn's poetry. Alan Hogarth is the Postdoctoral \\ Research Associate working with Mel Evans on the computational stylistics and author attribution testing. \\ The discussion focuses on the scope and principles of editing the poetry of Aphra Behn, the role of \\ stylometry in establishing the corpus, the status of work, a few particular poems, and some surprises.
}

\section{Keywords}

poetry, Restoration, attribution, computational stylistics, drama, Burnet

Creative Commons License

cc) (i) (8)

This work is licensed under a Creative Commons Attribution-Noncommercial 4.0 License 
Editing Aphra Behn in the Digital Age: An Interview with Gillian Wright and Alan Hogarth

During a brilliant and unseasonably warm week in June 2018, I attended the Aphra Behn Europe Conference on Early-Modern Women Writers: New Methodologies, Resources, and Theoretical Approaches, hosted by Sarah Prescott of the University College Dublin and introduced by Maureen Duffy. The conference was co-organized by Claire Bowditch, and she and Elaine Hobby led off sessions with a review and update on the Cambridge University Press edition of the Complete Works of Aphra Behn. The project, supported by fellowships from individual libraries and a generous grant from the Arts and Humanities Research Council, will yield eight volumes of Behn's work, fully collated and newly edited, including all works known or believed to be by Aphra Behn, and, for the first time, her letters. Additionally, the project will produce new research methodologies, data based on the computational analysis of the marked-up texts of Behn's works and a digital exhibit. Bowditch and Hobby explained the work will be published in tranches over a series of years (2020-2022), and they detailed the painstaking process of collating texts that has led them to rare book libraries around the world. Bowditch and Hobby are primarily responsible for the collation of the complete oeuvre of Behn's work, comparing at least ten copies of every text and noting the variations. Only one securely-attested manuscript version of a literary text by Behn exists in her own hand-the poem "To the Memory of Edmund Waller" - and without a body of autograph manuscripts to compare, the editors have relied upon print versions to establish an authoritative text. Given the conditions of print production in the late seventeenth century, the editors were not surprised - and often delighted — by the number and meaning of the variations among the copies they examined. Bowditch and Hobby also shared with us the rich history of annotations they've found in Behn's work, a set of paratexts that provides informative frames of reference for Behn and her readers. Not insignificantly, the marginalia sometimes point to the identities of people who inspired the texts, though at times it becomes clear that individual readers projected their own experiences onto the scripts.

Hobby and Bowditch belong to a core team of editors for the CUP Aphra Behn project that includes Gillian Wright, Mel Evans, and Postdoctoral Research Associate Alan Hogarth. Mel Evans (who was unable to attend the conference) leads the work with Hogarth to develop computational linguistic methods and material to investigate the authorship of works of dubious origin. Gillian Wright is the editor of Behn's poetry to be published in Volume V in Tranche B, slated for September 2020. While Bowditch and Hobby are collating the plays, fiction, translations, and letters of Behn, Wright has taken over the collation of poetry. If print-house practices in general led to multiple variants in works by a single author, the particular nature of poetic texts - often topical, and published in more than one version - make determining an authoritative text for the poetry that much more challenging. In fact, a theme that emerged over the course of our meeting was the exceptionality of poetry in the editorial process for Behn's work, and, indeed, the complexity of Wright's job in editing it. Many of the Behn volumes are flagged with works of dubious authorship that will be scrutinized in multiple ways, including computational analysis. Bowditch and Hobby flagged the entire volume of poetry as under scrutiny. As you shall see, it is not entirely the case that all authorship attributions in Behn's poetry are under question, but a considerable number of poems are being looked at anew. 
Hogarth shared the next session with Wright, and they presented "(Some of) the Challenges" in editing Aphra Behn. Their papers provide some key context for the interview that follows, and so I highlight just a few takeaways.

A unique feature of this government-funded project is the implementation of digital methods to determine authorship. Evans and Hogarth have been preparing the Behn texts for computational analysis while also establishing the best methodology to determine attribution. The computational work is an important and innovative supplement to the editing work done by previous scholars and the current core team, but it is not meant to be evidence used in isolation from the informed human interpretation of texts. Hogarth explained that their source texts are mostly digitized files from the Early English Books Online Text Creation Partnership (EEBOTCP) files that they clean and normalize using VARD 2 software. EEBO-TCP files, although an extremely valuable resource, are often imperfect, containing non-alphanumeric characters that need to be removed before any analysis can take place. VARD modernizes spelling, so that every instance of the same word can be counted, and then contractions are expanded manually (e.g. 'it's' and 'I'm' to 'it is' and ' $I$ am'), so that all of the most common words are accounted for. Finally, the texts are tagged for analysis, using TEI-structured XML. This is a labor-intensive process; but, Hogarth explains, achieving textual continuity across the sample corpora increases the accuracy and reliability of tests. The next step is to establish Behn's authorial "fingerprint." When it comes to assessing linguistic features for authorship, one of the most reliable measures across genres, time-periods and languages is most frequent words (MFW). Most frequent words, in large part, comprise function words (e.g. 'the', 'a', 'is'), and tend to return accurate results because of the unconscious nature of their distribution throughout a text; but also because they are unrelated to topic. This means that, regardless of genre or period, the authorship signal emerges strongly when tests are run with this measure.

To find Behn's "linguistic fingerprint," Evans and Hogarth tested a corpus of known texts by Behn against a corpus of contemporary work from the period. Once a linguistic profile for each group was established, the texts of dubious authorship were introduced and assessed according to their similarity with the Behn and contemporary groups. Standard statistical tests, including principal component analysis (PCA) and cluster analysis, were run to find a probability rating for each of the dubia. PCA measures variance across the population of texts-so, for example, 100MFW might be counted for each text and then plotted in two dimensions (see fig. 2). Cluster analysis is another exploratory way of accounting for similarity and difference - it can be read as a hierarchical tree diagram, with each branch indicating the closeness of groupings. The smaller the distance, the greater the similarity (see fig. 1). (For a helpful introduction to their work, see Evans' blog post: "First Steps: Learning the Art of Computational Stylistics.") At this point, the team has concluded work on the dubious drama texts, including The Revenge (1680) and The Woman Turn'd Bully (1675), and delivered some convincing preliminary results that will be turned back to the editors for analysis. See below to find out those conclusions. Next the team will move on to prose fiction, particularly the three volumes of the controversial Love-Letters between a Nobleman and his Sister. ${ }^{1}$ Poetry will be analyzed later this year.

For Wright, the purpose of the new volume of Behn's poetry is to provide a reliable edition and a case study for the twenty-first century reader encountering Restoration poetry. In conceiving the volume, Wright takes into account the historical and social construct of gender that informs 
Behn's writing without making specific feminist editorial interventions (such as might be made in an eclectic edition as theorized by D.C. Greetham, 1999). Instead Wright follows foundational principles helpfully outlined by Dirk van Hulle and Peter Shillingsburg, in "Orientations to Text, Revisited" (Studies in Bibliography 2015). In particular, the most relevant categories for Behn are "material orientation," which includes the lexical and bibliographical conditions of the text; "causal orientation," which concerns the text as a social product co-created by author, scribes, publishers, printers, agents, etc.; and "aesthetic orientation," which may consider how a text can satisfy current academic or commercial norms. The content for volume V stands thusly: c 11,485 lines of verse by Behn; 655 lines of commendatory verse from Poems upon Several Occasions (1684) and c 2200 words of prose introductions.

Gillian Wright and Alan Hogarth met with me on the morning of the second day of the conference to talk more specifically about their work on the poetry volume.

LR: Today ${ }^{2}$ we have Gillian Wright of the University of Birmingham and Alan Hogarth of University of Leicester talking about the Cambridge University Press edition of Aphra Behn's work, and specifically the volume of Behn's poetry.

To begin I'd like to ask how each of you got involved in the Aphra Behn edition. So perhaps Gillian you could start?

GW: Probably the first intimation or contact for the edition came as far back as 2012, in fact, in relation to a previous meeting of the Aphra Behn Europe Society. Elaine Hobby and Claire Bowditch organized the big Aphra Behn conference in Loughborough [in 2012]. I attended that conference. About that time, I was completing a book on women's poetry in the seventeenth century. ${ }^{3}$ I hadn't written very much about Aphra Behn in that book but I did have a section on her in my conclusion. I presented a paper at the conference based on what I'd said about Behn in that conclusion, and they liked what they heard. And so, when plans started to firm up about a year or so later - or at least planning to take shape - for an edition, Elaine and Claire asked me to join the team with particular responsibility for the poetry. And I've been on board since.

LR: You are also a general editor, right?

GW: I am a general editor, yes. There are four general editors altogether: Elaine Hobby, Claire Bowditch, Mel Evans, and me. And we share the responsibilities of organizing the edition and reviewing the draft edited texts as they come in. But my particular editorial responsibility is the poetry, which is going to be volume five in the print edition.

LR: Alan, how did you get involved in this?

AH: I got involved a year ago. My background is in textual computational approaches to literature. I worked on a previous project called Visualizing English Print that came to an end last year, when I saw the Aphra Behn job advertised, and I thought this is exactly the kind of thing I want to get involved in. Such a major edition, such important work. So I applied for the job, and thankfully I was deemed worthy.

LR: What is the type of work you are doing now on the edition? 
AH: Attribution experiments. We are essentially trying to discover or verify what Behn wrote. Are certain dubious texts actually by Behn or perhaps by another author? So we are starting with the drama, and we moved on to the prose just now, and the poetry will come maybe around about August or thereabouts.

GW: It might be worth saying that one reason why the work has been organized that way is that edition is going to be published in tranches. Three different tranches over a period of about two or three years. And so, in working on the attribution Mel and Alan have been working first of all on the genres which are in the first tranche. The poetry is further down the line. That's why drama was the first port of call.

LR: Gillian, what are some of the principles used to establish the corpus of poems by Aphra Behn; you spoke yesterday about core editorial principles, but, can you tell us more specifically what are you including and what are you basing that on?

GW: We are taking simultaneously quite a conservative and quite a liberal approach to inclusion. One of the things we do want the edition to do is to move further in the direction of defining the canon of Aphra Behn's works. I've deliberately put that quite cautiously because if we have learnt nothing else about canonicity, we've learnt that it is always changing. And it is unrealistic to suppose that any one person has got the last word on the subject. But we do want to take the debate a bit further than it's been in recent years. We start with the principle that if the work was attributed to Behn in her lifetime then we consider it her work. That's a fairly straightforward beginning. Things then start getting more complicated.

A large subsection of the questionable texts comprises those that were attributed to Behn shortly after her death. No one's ever quite known in those cases whether they are genuinely her works or whether they were opportunistically attributed to her. So that's a category of works that needs to be considered. There are also some works that were published in her lifetime that had been thought to be attributed to her but the attribution, when closely examined, turns out to be a little bit questionable. And one such poem, actually one that was mentioned yesterday, [is] the Letter to Mr. Creech (Miscellany 1685). That's included in a collection published during Behn's lifetime, and edited by her, but in the collection, it is signed only by a single initial: "A." And that's the basis for the attribution to Behn, which is actually quite a shaky basis. [This] is why we want to look again at the authorship of that poem. That's the respect in which we are being quite conservative: we are reexamining these attributions, some of which have not been looked at as much as they might lately.

However, we are taking into account the fact that even if it should prove that some of these attributions don't stand up to scrutiny, they nonetheless form a part of the way that Aphra Behn as an author has been historically understood. If we think the attribution is historically interesting, or if it is a matter of the balance of probabilities as to whether we think it is her work or not, the work will be included in the edition, but the issues surrounding the attribution will be very clearly described and flagged up to the reader.

LR: That's a really interesting case, because the relationship between Creech and Behn is founded in some ways on the assumption that she wrote this poem. 
GW: There are two poems to Creech. One of them is the commendatory poem she wrote in his translation of Lucretius. That one isn't in question. That's a wonderful poem, and as our discussion yesterday showed, it throws up all sorts of issues to do with Behn's engagement with learned culture, her knowledge of Latin, her interest in the philosophy of the time, Lucretius, libertinism, etc. There is another poem, one that Elaine and Claire were quoting - a much more jocular poem - when she talks of going out and falling in the street in bad weather when she had been on her way to see Creech. The poem is framed as an apology... "this is why I wasn't able to meet you."

\section{LR: Right.}

GW: So, this is, in some ways, quite an unusual poem within Behn's corpus because compared to other poets of her time, such as Rochester, there are not actually very many poems which show her engaged with the nitty gritty of street life in contemporary London. We think of the equivalent of Rochester or Oldham being buttonholed in the street. They have to talk with a bore for half an hour, and [we] find out about Restoration culture in the process. This poem to Creech is almost the only such poem in the Behn canon. We want to look into the attribution anyway, but if we were to decide that it is not by Behn, it would make quite a difference in how we think about Behn's works.

LR: That's very interesting. I hadn't thought about [Behn's poems] in terms of the city, but that's absolutely true.

Let's turn to the next question. It may be premature to ask, Alan, but in terms of determining the oeuvre or the canon, what role does stylometry or digital analysis play?

AH: Well it forms one part of it, as Gillian was saying, about the principles of editing. So, authorship attribution and stylometry complement that part of editorial practice that is interested in the material, lexical basis of the texts; there are a whole host of issues that will be addressed in the textual introductions to each text that will consider stylometric evidence, but also, historical, bibliographical and performative issues as well. Stylometry does provide a nice, quantifiable example of probability in terms of what an author writes.

LR: In terms of editorial work, stylometry has been around for decades. I think of Harold Love, for example, and the edition of Rochester he was working on (Wilmot 1999).

GW: [nodding] With John Burrows.

LR: So, it is not as though this is the first time it has been used in a major edition, but at the level of computational analysis, this is a pretty remarkable element for the Cambridge edition of Aphra Behn.

GW: I think so, yes. Alan would know more about this than I do. But another example that might be worth mentioning is the work that was done in relation to the Shakespeare canon. The recent edition of the Oxford Shakespeare. But after that I would have thought this is one of the biggest projects of its kind that has been.

AH: Absolutely. And first of a female author to my knowledge as well. It's an important step. 
The Oxford Shakespeare is a good example of what we're doing, some of the same things. We've been following Hugh Craig's method, he's an advisor on the project. He's done a lot of successful and convincing work in Shakespeare attribution.

LR: That's a good precedent.

And so, what do your preliminary results suggest? For the sake of the interview could you highlight some of the preliminary results of the digital analysis? What's in/what's out? Would that be a fair question at this point? It's not really related to poetry per se.

GW: As far as the poetry is concerned, I think we need to put you on hold about that because the main phase of the investigation is going to take place later this summer.

AH: At the moment, because what we've done until now are only the preliminary investigations, and most of these results have not even been passed onto the editors yet for their perspectives, we can only tell you what the stylometric results are indicating. And this, of course, is only one part of the whole makeup of information that will be addressed by the edition's editors.

I can give you some of the preliminary results for drama. This I presented in the talk yesterday so it is not really secret. The Revenge [a play that was published anonymously, but widely thought to be by Behn] is looking pretty much like Behn at the moment (see fig. 1). We've conducted a whole series of tests and the play consistently groups, or clusters, with the Behn set.
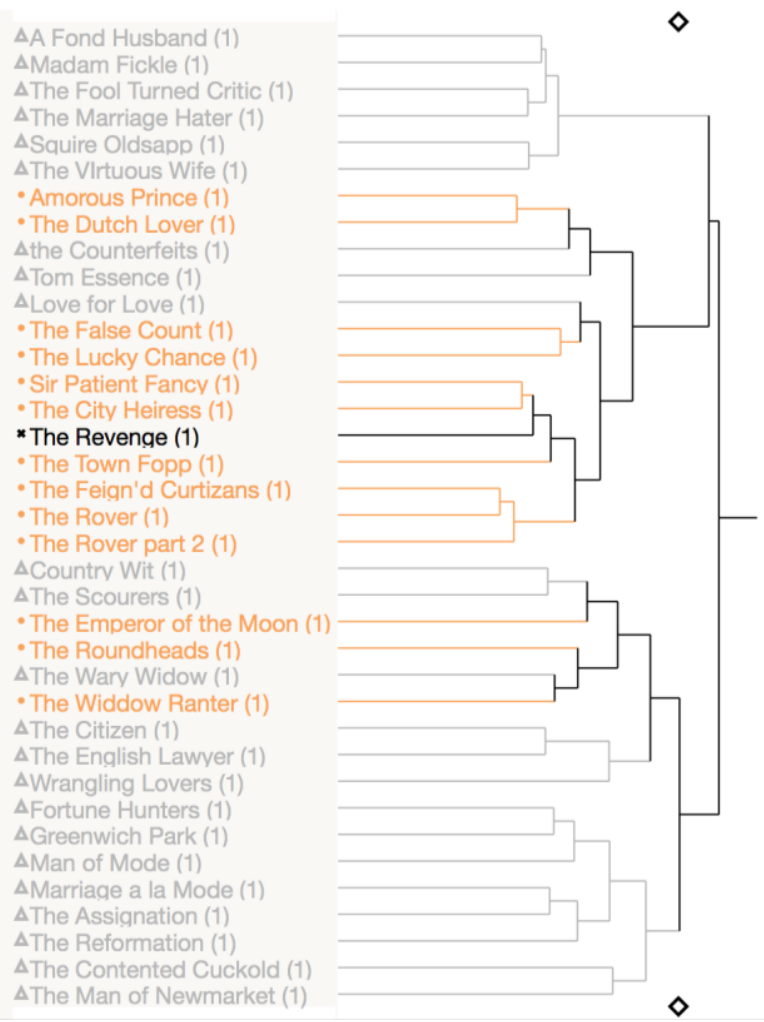

Figure 1. Cluster analysis; 100MFW; test text, The Revenge (1680) 
Another one we are quite sure about is The Woman Turn'd Bully; it's definitely NOT by Behn, according to the tests, that is. A range of tests indicated that this is a contemporary play, based on the relative dissimilarity of its language to that of Behn's comedies (see e.g. fig. 2). We might conduct another series of tests to find out who the author might be.

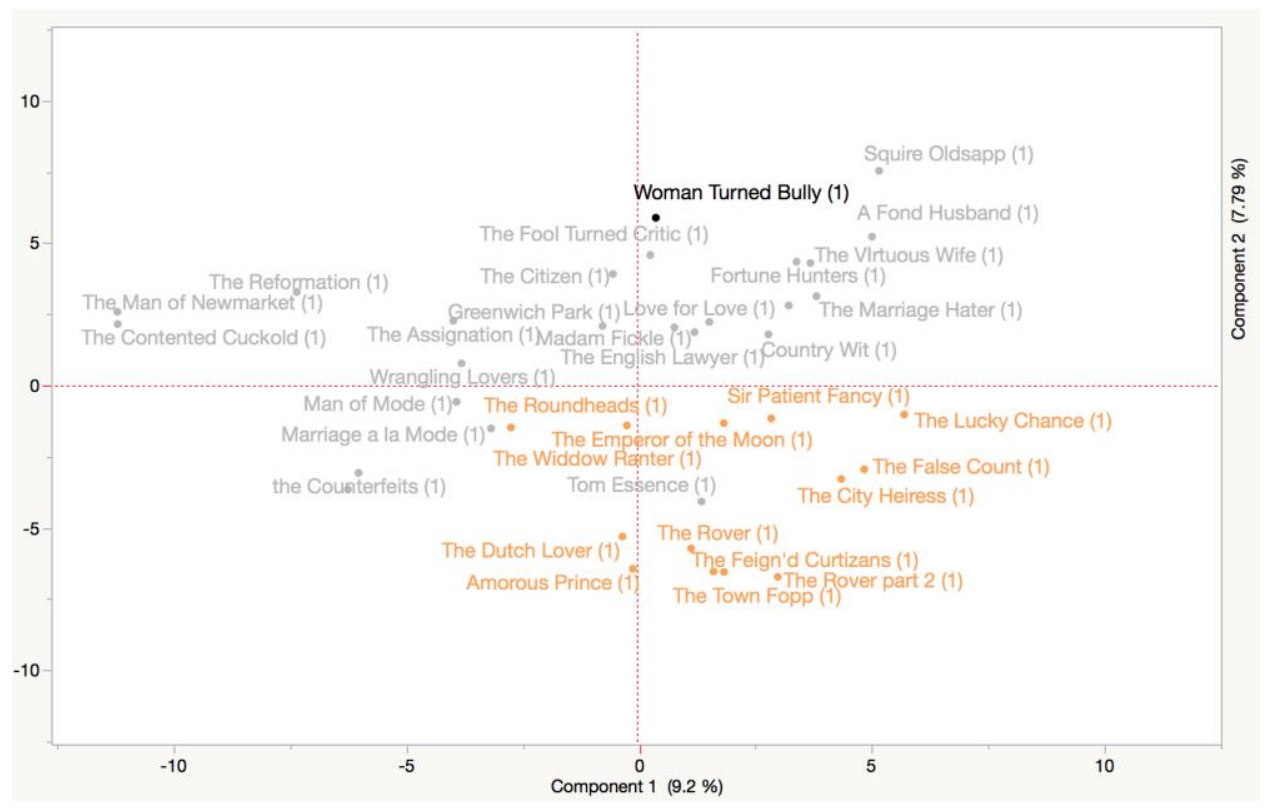

Figure 2. PCA analysis; 100MFW; test text, The Woman Turned Bully (1675)

\section{LR: Oh, very good!}

AH: With the other plays that we're looking at in the drama corpus-The Counterfeit Bridegroom and The Debauchee - we don't have any conclusive results yet. There are some indications that the language is very much like Behn's, and other indications that it's not. As I mentioned yesterday, this could be a collaborative thing.

LR: A question that arises for me about the Creech poem, for example, and the methodology used for the drama: can you do the same level of analysis on such a short work as the Creech poem, with the same validity as you would for the longer works, like a full drama?

AH: That's what we are hoping to find out. We can always do the analysis using smaller segments of text. I showed an example yesterday, of segmenting drama texts by one hundred words blocks. So, we can do something similar with the poetry. Most of the poetry is of varying lengths, and we could create segments of equal size to conduct the analysis. I think we have a good body of poetry that we know is by Behn. Poetic genre is also something we need to consider, as genre is linguistically determined - to establish authorship we sometimes have to nullify the genre signal by limiting the tests to a single genre at a time. With good numbers of poems in different genres, we can identify a strong baseline stylistic signature for Behn, when compared to a corpus of other poems from the period. 
GW: One of the things we kept saying yesterday is that the poetry is especially complicated, and I think that's going to be the case with regard to attribution as well as everything else. And the length issue that you raise is particularly problematical with respect to the poetry.

LR: I think about the assumptions underlying stylometry, that most of the short words, the function words, are used unconsciously in prose or even in drama, though less so in drama. But in poetry everything seems to be so consciously constructed, I'm wondering about the validity.

AH: Well it will be interesting to find out. There are other measures, such as most frequent ngrams and character $n$-grams, that may return coherent results for the poetry. The question of the inherent intentionality of poetry will certainly be an exciting problem to contend with.

LR: Ok-we'll wait on that question. We'll be expecting something interesting coming in the future.

My next question is, what can we as readers expect from the edition in terms of annotations? The previous editions, in the work of Montague Summers, for example, the annotations are richly historical, anecdotal, fun, but a little uncertain of their validity and trustworthiness. And then with Janet Todd there's just very little annotation. The headnotes have good information about sources, but what can we expect from the Cambridge edition? What is your philosophy of annotation?

GW: I'm not sure I've got so far as philosophy, but the two practical issues you raise are trustworthiness and quantity. And in both these respects we hope to provide more than previous editors have been able to do. It's worth saying, to take the Todd edition for instance, it was produced by a single person working with much more limited resources than we have nowadays. So it is an utterly extraordinary achievement. For our own purposes, we want to have much more substantial supporting materials, so headnotes to individual poems and annotations to individual poems. Annotations will be historically informed and informed in terms of the literature, so that we make connections with sources, and we are charting intertextual allusions and that kind of thing. We are trying as far as possible not to be too literary-critical in the way we draw up our annotations; by which I mean, what I think of a particular poem is not necessarily the point. Of course it comes into it, because I'm the thinking person who is doing the annotation. But as to my own judgement about what a particular line might mean, I'm going as much as possible to hold back on that and simply point out comparisons that seem relevant.

We're also going to make it a strict policy to provide sources for whatever we can. No factual assertions that can't be backed up with relation to a published source, either a reliable modern scholarly source or an early modern source. We also want to have the annotations on the same page as the text so readers don't have to keep turning to the back of the book.

LR: Oh Good!! I think that's the way to go. Thank you so much.

GW: That's the idea anyway, and CUP are on board with that. Needless to say, we don't want the sort of situation where there is so much annotation on a page that you can't see the poem. This will be a process of negotiation but that's the aim we are starting with. 
LR: That's wonderful. So, where are you in the process? That might be a daunting question for you.

GW: I do find it a rather daunting question because it is a big corpus. And a lot of what I've been doing so far has been preparatory work. I spoke yesterday about various processes of list making, looking at the corpus as fully as possible from various literary points of view, trying to ascertain what attribution bases for each of these poems are, which of these can we consider to be reliably Behn's, which are a bit more dubious, and what degree of dubiety is in question in each case. I've also been giving quite a lot of conference papers about Behn's poetry, and I've been making a point to try to work my way around the entire corpus to get my mind around it. Because as I was implying to begin with, when I came to this project I was a specialist in women's writing but not necessarily a specialist in Aphra Behn, so I've had quite a lot to learn about her work, but I've had an opportunity to learn it. I've been feeling my way around her poetry collection, Poems upon Several Occasions, which is the bit of her corpus I knew best. I've been looking at the translations, her royal poems, her versions of Aesop's fables which are not so well known and which are fascinating. I've also been doing a parallel project, which is a book about Restoration poetry, to try and really, really kind of get a very firm grip on the period.

And as well I've edited some poems. But I think the bulk of the editorial work is going to be done in the next year.

LR: What do you hope or plan for the reader of this volume to take away from this new edition? With this long project, you must have some idea or ideal of what you're shooting for.

GW: Well, we've all come to the project with a huge amount of enthusiasm about Aphra Behn, and just want to make her works better known, and that really is the key thing. As we have said before, Behn's works are popular with students but they're very unevenly known. One or two of them possibly known quite well, and the rest of her absolutely fascinating corpus is relatively little read. So we want to get the full range of her works read. We also want her to be appreciated as a Restoration author in a wide range of genres, which is utterly remarkable for the period, and not just for the period but for other periods as well; very, very few authors are as accomplished and pioneering across a spread of genres as she was. We also want to provide readers with a way into Restoration culture. There are a lot of clichés about the Restoration. It is a comparatively little-known period, but when it is known it's known in terms of a few big clichés. What we want to do is provide richly worked case studies that will give students and other readers insights into just how much was going on, how much was changing in the course of the twenty years that Behn was operating, and how much you can learn through her writing about the theatre, about the institutions of literature, about the politics. There are a separate set of objectives for the attribution work, but Alan can speak better about that.

AH: Well again we are interested in promoting the work. Mel and I are going to be publishing a separate set of articles that go along with the edition to promote the work that we've been doing, and hope that the method can be rolled out to other editions as well. ${ }^{4} \mathrm{We}$ are also aiming to incorporate an interactive stylometric display into the Behn exhibition that is planned to coincide with the launch of the edition in 2020. This exhibition will take place in The National Archives, and is centered around Behn's spying letters. 
LR: That's wonderful. I think computational analysis is a really huge step in the work we are doing in literary studies; methodologically and for what we know about the authors themselves.

AH: I think the edition's approach is good because it captures all these different elements. Recently, there's been some antagonism between attributionists and scholars who see attribution as existing in a vacuum, cut off from the kinds of evidence that are produced by literary historical and bibliographic research. Hopefully, the edition goes some way toward synthesizing these methods.

LR: That's a really good point. I think a lot of literary scholars do feel antagonistic toward these computational methods, and to have this example of a coordinated and supportive effort will be very important for moving forward. I'm very excited about that.

I want to go back to something you said, Gillian, regarding the twenty years of the Restoration when Behn was writing and the remarkable changes she witnessed. Can you identify maybe one or two poems - maybe a beginning and a late poem - that show or mark that transition so that the modern reader could see it most clearly?

GW: In some ways that is quite a difficult question because as I said Behn was writing for over at least twenty years from around 1670 until 1689 when she died. Most of her poems were not published until the 1680s, and so knowing which the early poems are is in some cases a little bit complicated. One answer to that question is that towards the end of her life, she produced a series of poems on royal events which in some ways are responses to circumstances. She's writing about births and she writes about the death of Charles II, the accession of James II. She writes about a series of events for which there is no equivalent in the 1670s so she couldn't have done that earlier. Her earlier lyrics ... three of the first poems of hers that were published appeared in a collection called Covent Garden Drollery in 1672. One of those is a poem on a character called Jemmy. It's one of a number of poems which have been linked by Behn scholars with the Duke of Monmouth. My feeling . . . what of course I wonder is whether if Behn had died, say, in 1675 whether scholars now if they're looking at those poems, whether any of them would make the link to Monmouth. I think the link to Monmouth is to a great extent made in the light of what happened later - the fact that he led a rebellion and became an ever more controversial figure in the 1680s. One of the issues I think we have to contend with in Behn scholarship is the fact of hindsight: with the fact that for the last twelve years of her life she was living through extremely tumultuous times, unprecedented events, Popish plot, the Exclusion Crisis, the revolution of 1688. It's quite difficult to exclude knowledge of those events when you read her earlier work, but one of the things I want to do is try to think what it would actually mean to a reader of 1672 .

LR: Yes, that's going to be a real challenge.

GW: Well, of course, you can't really do it. You can't unknow the things you know about what happened later, but you can conduct a kind of imaginative exercise and try to push all that information away.

LR: [nodding] What if you didn't know that Monmouth was going to lead a rebellion; what if you didn't know that James II was going to become king? Those sorts of things are fascinating. 
One of the poems that I am most interested in when I teach and when I read Behn, is one of her last poems, her poem to the Bishop Burnet. How does that poem figure in to some of the questions you've just been talking about? Because that is an unthinkable poem in the 1670s.

GW: Absolutely unthinkable, for all sorts of reasons. One of the most fascinating things about that poem is that we know that in a sense Behn and Burnet had a history. There's a correspondence on record between Burnet and Anne Wharton in 1682 in which he described Behn as an abominably vile woman and advised Wharton not to have any more to do with her than she could help. So the notion that we think Burnet later approached Behn and asked her to write for William is one of the many historical ironies about Behn's life. The Pindarick to Burnet is interesting in terms of historical context; it's very ironic, it's very tantalizing because it is happening so late in Behn's life, just when life has overturned completely, the political circumstances have overturned completely. It's also fascinating in terms of what Behn's doing with the genre. Her earlier Pindaricks are very much on royal subjects, they're addressed to royal addressees, and they are very adulatory and complimentary; whereas the Pindarick to Burnet is filled with ironies, and slyness, and all sorts of expressions that look like compliments but are actually quite the reverse. So she's doing something very interesting with the genre right at the very end of her life.

LR: I remember Todd [as a biographer of Behn (1997, p. 7)] talking about the person you imagine as the subject of your biography, the one you want her to be, and I always imagine the Behn of the Burnet poem is the real Aphra Behn. For me that's where I see her emerging and saying what she really thinks. That could be just what I want her to be and not the reality.

GW: It's a poem that divides scholars. I've recently worked on my draft of the edition of that poem, and so I've been looking at the scholarship on it. Scholars divide in all sorts of ways. There are certainly those who see it as Behn's last principled rejection of Burnet and everything that he stands for, and there are others yet who actually think it is a more ambiguous poem than that; that she's clearing a certain space in which she might do something.

\section{LR: The survivor.}

GW: Yes. At least it needs to be read in relation to her near contemporary Congratulatory Poem to Queen Mary. At the same time that she is telling Burnet that she won't write for William effectively she is writing for Mary, which is something that not every proto-Jacobite would have been prepared to do. There were certainly some Jacobites who were prepared to be a bit more accommodating with Mary because she had a better claim to the throne. But there were others who felt that Mary was even worse than William because she'd betrayed her father. So her willingness to write for Mary does indeed need to be read in relation to what she's saying to Burnet in her poem to him.

LR: Now this of course opens up a whole other line of inquiry I'd love to pursue, and that would be the desire to see the feminocentric Behn [in this example] as well. But we need to wrap this up.

I'll ask just one final question of both of you. Is there any other information that you would like to share with $A B O$ readers at this moment in the process? 
AH: Watch this space.

GW: I think that's basically it. I think they will find in this edition a very rich set of resources about Aphra Behn herself and also about late seventeenth century literary culture. We want the edition to do both.

AH: Hopefully, we'll have some happy news about attribution and maybe a few surprises there as well.

LR: Happiness and surprises. Thank you both very much for taking the time to do this.

\footnotetext{
${ }^{1}$ For evidence of the controversy over authorship, see Leah Orr, "Attribution Problems in the Fiction of Aphra Behn.” The Modern Language Review, vol. 108, no. 1, 2013, pp. 30-51. JSTOR, www.jstor.org/stable/10.5699/modelangrevi.108.1.0030.

${ }^{2}$ Recorded Thursday June 28, 2018. University College Dublin, Ireland.

${ }^{3}$ See Gillian Wright, Producing Women's Poetry, 1600-1730: Text and Paratext, Manuscript and Print. Cambridge UP, 2013.

${ }^{4}$ See Mel Evans, "Style and Chronology: A Stylometric Investigation of Aphra Behn's Dramatic Style and the Dating of The Young King," Language and Literature, vol. 27, no. 2, May 2018, pp. 103-132.
} 
Works Cited

Behn, Aphra. "A Letter to Mr. Creech at Oxford,” Miscellany,1685.

---. The Works of Aphra Behn. Edited by Montague Summers, 6 vols, Heinemann, 1915.

---. The Works of Aphra Behn. Edited by Janet Todd, 7 vols, Ohio State UP, 1992-6.

Early English Books Online Text Creation Partnership. University of Michigan Library, http://www.textcreationpartnership.org/tcp-eebo/.

Editing Aphra Behn in the Digital Age. https://www.aphrabehn.online/.

Craig, H., editor. Shakespeare, Computers, and the Mystery of Authorship. Cambridge UP, 2009, https://www.cambridge.org/core/books/shakespeare-computers-and-the-mystery-ofauthorship/89F8AEF655C5FFD3D73E500870C71972.

Craig, H., and Brett Hirsch. Style, Computers, and Early Modern Drama: Beyond Authorship. Cambridge UP, 2018, http://www.cambridge.org/us/academic/subjects/literature/renaissance-and-early-modernliterature/style-computers-and-early-modern-drama-beyondauthorship? format=HB\&isbn=9781107191013.

Evans, Mel. "First Steps: Learning the Art of Computational Stylistics." Editing Aphra Behn in the Digital Age, March 6, 2018, https://www.aphrabehn.online/first-steps-learning-theart-of-computational-stylistics/.

Greetham, D. C. Theories of the Text. Oxford UP, 1999.

Rochester, John Wilmot. The Works of John Wilmot, Earl of Rochester. Edited by Harold Love, Oxford UP, 1999.

Shakespeare, William. The New Oxford Shakespeare: Critical Reference Edition, general editors, Gary Taylor, John Jowett, Terri Bourus, Gabriel Egan. Oxford UP, 2017, http://www.oxfordscholarlyeditions.com/nos.

TEI: Text Encoding Initiative. http://www.tei-c.org/.

Todd, Janet. The Secret Life of Aphra Behn. Rutgers UP, 1997.

van Hulle, Dirk and Peter Shillingsburg. "Orientations to Text, Revisited," Studies in Bibliography, vol. 59, no. 1, 2015, pp. 27-44.

VARD 2. http://ucrel.lancs.ac.uk/vard/about/.

Visualizing English Print Project. Visualizing English Print: Textual Analysis of the Printed Record. webmaster, Deidre Stuffer. The Visualizing English Print Project, 2016, http://vep.cs.wisc.edu.

XML: Extensible Markup Language, https://www.w3.org/XML/. 
ABO: Interactive Journal for Women in the Arts, 1640-1830, Vol. 8 [2018], Iss. 2, Art. 3 